\title{
ARTIFICIAL POLLINATION AND FRUIT QUALITY IN RED PITAYA
}

\author{
POLINIZAÇÃO ARTIFICIAL E QUALIDADE DE FRUTO EM PITAIA VERMELHA
}

\section{Thatiane Padilha de MENEZES ${ }^{1}$; José Darlan RAMOS ${ }^{2}$; Adriano Teodoro BRUZI²; Ana Cláudia COSTA ${ }^{3}$}

1. Agrônoma, Doutora em Agronomia, Universidade Federal de Lavras - UFLA, Lavras, MG, Brasil. thatiagro@yahoo.com.br; 2. Professor, Doutor, Departamento de Agricultura da UFLA, Lavras, MG, Brasil; 4. Professora, Doutora, Departamento de Agricultura, Universidade do Estado do Mato Grosso - Unemat, Sinop, MT, Brasil.

\begin{abstract}
Native of the Americas, pitaya is currently a fruit bearing plant in expansion in the domestic and international market and is an alternative source of revenue for small and large farmers. As some studies show the lack of efficiency of natural pollinators in fructification in pitaya, the purpose of this study was to evaluate the efficiency of manual self-pollination and of manual cross pollination in Hylocereus undatus in two periods of pollination. The experiment was carried out in the orchard of the Universidade Federal de Lavras (Federal University of Lavras) in a completely randomized design with a $2 \times 2$ factorial arrangement (two types of pollination and two flowering periods) with 15 replications, with one flower per replication. The flowers were bagged, emasculated and pollinated manually. The percentage of fruit set, longitudinal and transversal diameter of the fruit, mass of the fruit, pulp and peel, thickness of the peel, soluble solids contents, $\mathrm{pH}$, titratable acidity, ratio (soluble solids:titratable acidity), number of seeds per fruit and seed germination were evaluated. It may be concluded that pollination in red pitaya with its own pollen allows fructification. Flowers pollinated in Apr. result in fruit with physical characteristics superior to the fruit generated by pollination in Jan.
\end{abstract}

KEYWORDS: Cross pollination. Hylocereus undatus (Haw.) Britton \& Rose. Plant breeding. Selfpollination.

\section{INTRODUCTION}

Practically unknown 15 years ago, pitaya (or dragon fruit) currently occupies a growing niche in the European exotic fruit market (MIZRAHI et al., 1997; IMBERT et al., 2001). Red pitaya (Hylocereus undatus Haw.) is native to the Americas, being found in Costa Rica, Venezuela, Panama, Uruguay, Brazil, Colombia and Mexico, with the last two countries being the main world producers (CANTO, 1993).

The fruits of red pitaya is extremely red and attractive to consumers. It has a whitish pulp with an agreeable, slightly sweet flavor, and numerous tiny black-colored seeds (ANDRADE et al., 2005).

Its flowers are large, androgynous and very striking (GUNASENA et al., 2007), being pollinated by bats and moths (MERTEN, 2003). Bees are not efficient pollinators of Hylocereus undatus sp. (WEISS et al., 1994) due to the size of flowers and the arrangement of its parts (MERTEN, 2003). It has nocturnal anthesis with an approximate duration of 15 hours and it begins to close in the very early morning hours (MARQUES et al., 2011). After pollination, the beginning of fruit development is observed, characterized by desiccation of the flower remains (MARQUES et al., 2011).
Flowering episodes are cyclical and occur throughout the entire period of florescence. In the Southern hemisphere, florescence occurs from Nov. to Apr., with five to six flowering periods (LE BELLEC et al., 2006), and it is possible to observe plants with flower buds in the initial stage, buds in development, green fruit and ripe fruit in a single period (MARQUES et al., 2011).

In California, one of the main problems with growth of new regions of pitaya is the absence of pollinators (MERTEN, 2003). Thus, manual pollination has been suggested so as to increase fruit yield (GUNASENA et al., 2007).

In studies on flowering and pollination in pitaya, Weiss et al. (1994) reported that pollination flowers in an open stage are visited by bees and that pollen transfer is a result of the activity of these insects. Nevertheless, the authors observed that the fruit resulting from manual cross pollination were larger and heavier in relation to the fruit from open pollination. Le Bellec (2004), corroborating the results mentioned above, reports that the quality of the fruit resulting from natural pollination is generally less than that of fruit coming from manual cross pollination.

Therefore, the purpose of this study was to evaluate the quality of red pitaya fruit obtained from artificial pollination at two different periods of florescence. 


\section{MATERIALS AND METHODS}

The experiment was conducted in the fruitgrowing sector of the Universidade Federal de Lavras, MG, Brazil, from Jan. to May 2012. The climate in the region is the $\mathrm{Cwb}$ type, mild temperate (mesothermal), according to the Köppen classification. The climatic data of the experimental period are presented in Figure 1.

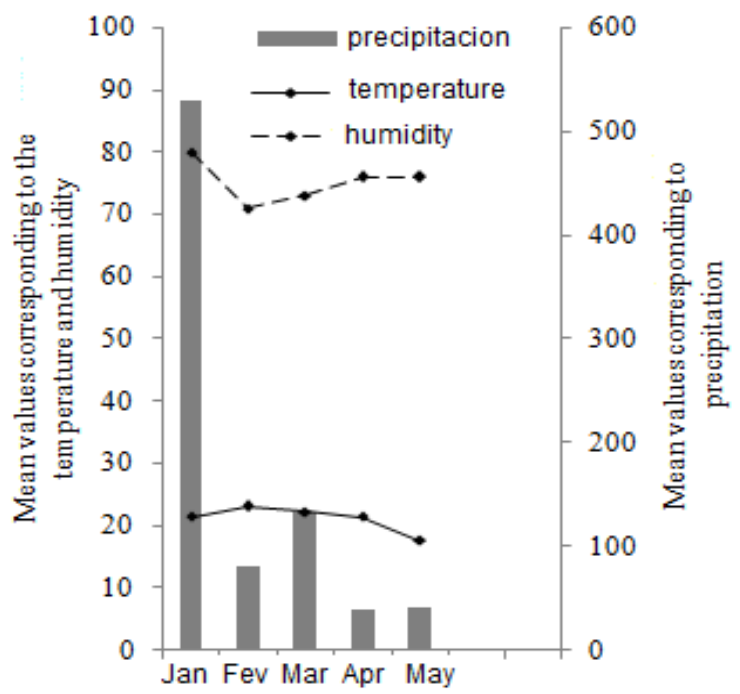

Figure 1. Mean values corresponding the temperature $\left({ }^{\circ} \mathrm{C}\right)$, humidity $(\%)$ and precipitation $(\mathrm{mm})$ during the experimental period. Climatology station of the Department of Engineering of UFLA, Lavras, MG (2012).

To conduct the experiment, eight plants of red pitaya [Hylocereus undatus (Haw.) Britton \& Rose] were used, at four years of age, at a spacing of $3.0 \times 3.0 \mathrm{~m}$, trained perpendicular to the soil on eucalyptus poles up to $1.80 \mathrm{~m}$. Phylloclades were supported by a trellis type structure made of bamboo over the poles.

A completely randomized experimental design was used, with a $2 \times 2$ factorial arrangement (two pollination periods - Jan. and Apr., and two types of manual pollination - self-pollination and cross pollination), with 15 replication, with one flower per replication.

The flowers were bagged before anthesis with non-woven fabric bags, with dimensions of $0,40 \times 0,22 \mathrm{~m}$, when the flowers were approximately $0,18 \mathrm{~m}$ in length. On the morning following anthesis, the bags were removed from the flowers and the flowers were emasculated. To carry out self pollination, the pollen of the emasculated flower was placed on the stigma of that flower with the aid of a brush and the flower was once more bagged to avoid pollination by insects. For cross pollination, the procedure was similar; however, the pollen used was provided by random neighboring plants.

Assessment of percentage of fruit set was made fifteen days after pollination and those flowers that were fertilized remained bagged until harvest of the ripe fruit, characterized by the red coloring of the peel.

After harvest of the fruit, its physical and chemical characteristics were assessed: mass of the fruit and mass of the pulp (using a digital balance and expressed in grams), transversal and longitudinal diameter of the fruit (by means of a digital caliper rule and expressed in $\mathrm{mm}$ ), thickness of the peel (using a digital caliper rule and expressed in $\mathrm{mm}$ ), titratable acidity (AT) $(\%), \mathrm{pH}$, soluble solids content (SS) - ${ }^{\circ}$ Brix (by means of a digital refractometer), ratio (soluble solids:titratable acidity), number of seeds per fruit (estimated by one hundred seed count in an eight fruit sample), total weight of seeds per fruit (by means of a digital balance and expressed in grams). For laboratory analyses, a completely randomized design was used with 10 replications, with one fruit per replication.

The viability of seeds formed in fruits obtained by artificial pollination was studied through the germination percentage of the seeds produced at 10 days after seeding. The seeds were extracted from the fruit with the aid of a sieve and running water, up to removal of the mucilage. Then they were placed to dry in the shade for 48 hours. For assessment of germination, the seeds were placed in a gerbox container, kept in a chamber at 
constant temperature at $25^{\circ} \mathrm{C}$ using paper as a substrate. A completely randomized experimental design was used with four replications of fifty seeds each.

The data obtained from the characteristics studied were submitted to analysis of variance and the mean values were compared by the Tukey test using the Sisvar program (Ferreira, 2000).

\section{RESULTS AND DISCUSSSION}

It may be observed that two types of pollination resulted in setting of fruit, however, in Apr. the percentage of fruit obtained is greater than that of January. Fruit set may possibly have been affected by the environmental conditions, since rainfall in Jan. was greater than in Apr., as shown in Figure 1, probably affecting the viability of the pollen grain.

In both pollination times, the fruit set was greatest through manual cross pollination, obtaining up to $93 \%$ fructification (Table 1). Weiss et al. (1994), studying breeding systems and type of pollination in Hylocereus undatus, obtained from $50 \%$ to $79.6 \%$ of fruit set in manually selfpollinated flowers. These authors had greater fruit setting through cross pollination of Hylocereus with clones of other species, achieving $100 \%$ fructification, and in flowers of Hylocereus isolates, there was no fruit set.

Table 1. Fructification percentage of manually pollinated red pitaya flowers at two different periods of florescence. Lavras, 2012.

\begin{tabular}{cccc}
\hline & Type of manual & \multicolumn{2}{c}{ Pollination time } \\
\cline { 3 - 4 } Source of variation & pollination & Jan. & Apr. \\
\hline \multirow{2}{*}{ Fructification $(\%)$} & Self-pollination & $66 \%$ & $80 \%$ \\
& Cross-pollination & $73 \%$ & $93 \%$ \\
\hline
\end{tabular}

As it was possible to obtain fruit by means of self-pollination, it may be inferred that there is no self-incompatibility for the clones evaluated. Nevertheless, a greater fruit setting rate was obtained by performing cross pollination.

It may be perceived that artificial pollination in red pitaya, using its own pollen, may be performed for the purpose of setting of fruit, and can substitute natural pollinizers. For Weiss et al. (1994), manual pollination may suitably be performed during the early morning hours, if economically possible. The authors also report that manual cross pollination results in high fruit setting, as well as obtaining heavier fruit in comparison with fruit from open pollination in Hylocereus spp.
Analyzing Table 2, it may be observed that the acidity and the ratio of the fruit were significantly affected by the type of pollination $(\mathrm{P})$, time period of pollination $(\mathrm{E})$ and by the interaction $(\mathrm{P} \times \mathrm{E})$. For the germination percentage, there was no significance, neither for type of pollination nor for the time period of pollination. As for the characteristics of longitudinal and transversal diameter, mass of the pulp, mass of the peel and number of seeds, there was a significant effect from the time period of pollination, as well as from the interaction. Differences were observed only from the time period of pollination for the factors of mass of the fruit, thickness of the peel, soluble solids content and $\mathrm{pH}$.

Table 2. Summary of analysis of variance for the characteristics of mass of the fruit (MF), mass of the pulp (MP), longitudinal diameter (DL), transversal diameter (DT), mass of the peel (MC), thickness of the peel (EC), number of seeds (NS), soluble solids content (SS), pH, titratable acidity (AT), ratio (SS/AT) and germination (GR) in red pitaya fruit manually pollinated at two different time periods. Lavras, 2012.

\begin{tabular}{|c|c|c|c|c|c|c|c|c|c|c|c|c|c|}
\hline \multicolumn{14}{|c|}{$\mathrm{Pr}>\mathrm{Fc}$} \\
\hline & & $\mathrm{MF}$ & $\mathrm{MP}$ & $\mathrm{DL}$ & DT & $\mathrm{MC}$ & $\mathrm{EC}$ & NS & $\mathrm{SS}$ & $\mathrm{pH}$ & AT & SS/AT & GR \\
\hline $\begin{array}{l}\text { Type of } \\
\text { pollination } \\
\text { (P) }\end{array}$ & 1 & 0.08 & 0.29 & 0.05 & 0.95 & 0.18 & 0.08 & $0.04^{*}$ & 0.20 & 0.08 & $0.0^{* *}$ & $0.0^{* * *}$ & 0.60 \\
\hline $\begin{array}{l}\text { Time period } \\
\text { (E) }\end{array}$ & 1 & $0.0^{* *}$ & $0.0^{* *}$ & $0.0^{* *}$ & $0.0^{* *}$ & $0.0^{* * *}$ & $0.0^{* * *}$ & $0.0^{* *}$ & $0.0^{* * *}$ & $0.0^{* *}$ & $0.0^{* *}$ & $0.00^{\text {*** }}$ & 0.6 \\
\hline $\mathrm{E} \times \mathrm{P}$ & 1 & 0.06 & $0.01^{*}$ & $0.0^{* *}$ & $0.02^{*}$ & $0.0^{* *}$ & 0.41 & $0.0^{* *}$ & 0.79 & 0.77 & $0.0^{* * *}$ & 0.51 & 0.13 \\
\hline $\mathrm{VC}(\%)$ & & 15.4 & 24.87 & 11.27 & 9.50 & 19.60 & 17.41 & 27.07 & 8.56 & 5.39 & 16.37 & 11.31 & 4.87 \\
\hline
\end{tabular}


Trought the Table 3 , it is possible to observe differences in Jan. in the self-pollinating fruit in relation to the fruit from cross pollination for the characteristics of longitudinal diameter, mass of the fruit, mass of the pulp and number of seeds. The mean values obtained for these traits of $83.41 \mathrm{~mm}$ for longitudinal diameter, $213.12 \mathrm{~g}$ for mass of the fruit, $114.01 \mathrm{~g}$ for mass of the pulp, and 1402.27 for the number of seeds per fruit, are greater than those found for the fruit derived from manual cross pollination in this same time period. Therefore, it is possible to infer that the mass of the fruit, the mass of the pulp and the number of seeds per fruit have a positive correlation.
Fruit pollinated in April differed only in relation to the mass of the peel, exhibiting on average $247.23 \mathrm{~g}$ and $197.95 \mathrm{~g}$ (Table 3) for fruit from manual cross pollination and manual selfpollination respectively.

Furthermore, in the same table, differences are seen in all the physical characteristics of the fruit assessed, with the mean values obtained being greater for the fruit pollinated in Apr., both for fruit from manual self-pollination and for fruit from manual cross pollination. These results indicate that the time period of pollination of the flowers has an influence on the physical attributes of the fruit.

Table 3. Physical characteristics related for longitudinal diameter (DL), transversal diameter (DT), mass of the fruit (MF), mass of the pulp (MP), mass of the peel (MC), thickness of the peel (EC) and number of seeds (NS) for red pitaya fruit resulting from two types of pollination and two time periods of pollination. Lavras, 2012.

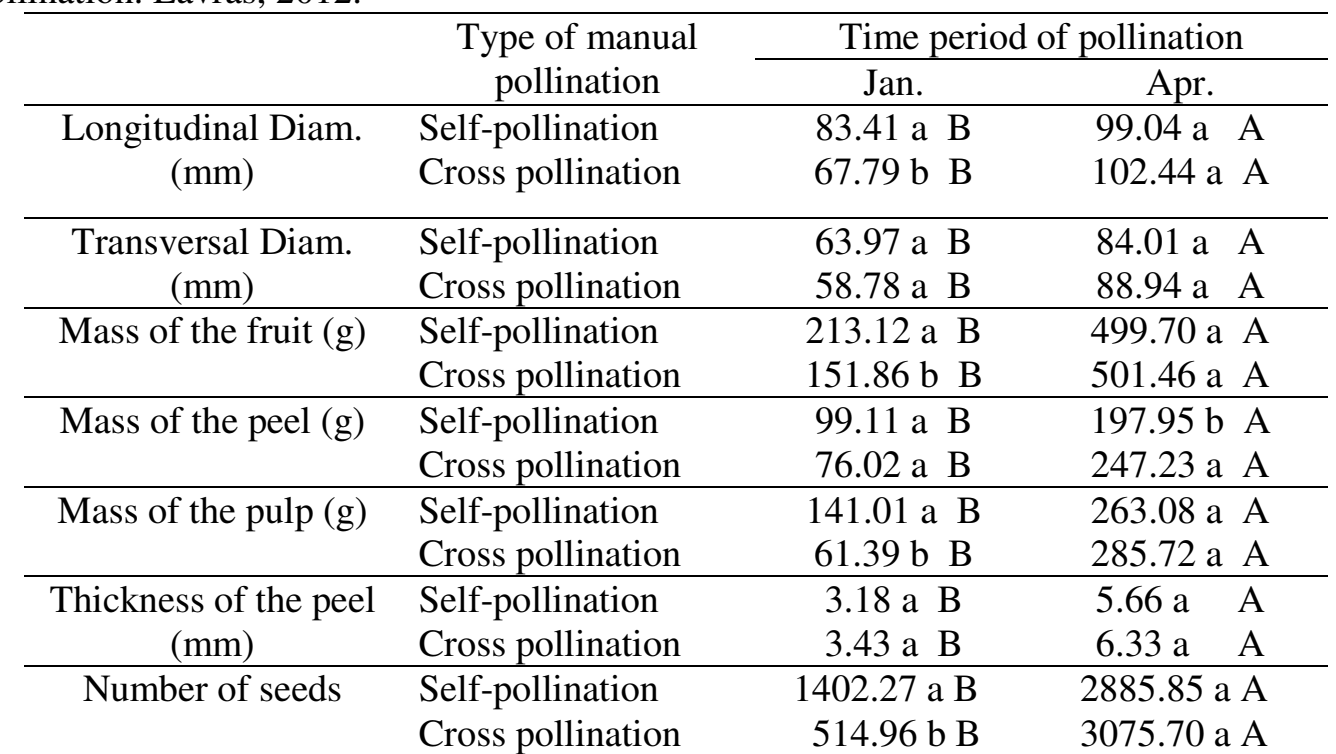

Mean values followed by the same small letter in the column and same capital letter in the line do not differ among themselves by the Tukey test at $1 \%$ probability.

Silva et al. (2011), studying the quality of pitaya fruit according to the time period of pollination, also observed the effect of the time period on the characteristics of the fruit in relation to mass of the pulp, \% of pulp, thickness of the peel, vitamin $\mathrm{C}$ and days to harvest, with the three last attributes being greater for flowers pollinated in Apr.

The results found in the fruit of flowers pollinated in Apr. for the two types of pollination are greater than those obtained by Moreira et al. (2011) in red pitaya working with different types of organic fertilization, with the exception of pulp yield, which showed similar values.

In relation to the number of seeds per fruit, differences are seen in relation to the time period of pollination of flowers, with the highest average amount of seed (3075.70) being observed in flowers pollinated in Apr., regardless of the type of pollination. Already in Jan., differences were seen in the number of seeds in relation to the type of pollination, with a greater value being observed in manually self-pollinated flowers (Table 3 ).

Weiss et al. (1994), studying pollen viability in pitaya, observed that the maximum percentage of ovules that developed in seeds was $23 \%$ in Selenicereus megalanthus, while in Hylocereus undatus it was $90 \%$. According to the authors, the low quantity of seeds found in Selenicereus megalanthus may be related to the viability and the germination of the pollen. In addition, they reported that a greater quantity of seeds and fruit weight may 
have been obtained from pollination from highly viable pollen from other clones of Selenicereus megalanthus or another Selenicereus spp.

Cisneros et al. (2011), studying seed development in three species of Hylocereus report that Hylocereus undatus produces a relatively high number of viable seeds, around 3800 seeds per fruit on average. Mizrahi et al. (2004) report a greater mean number of seeds per fruit in Hylocereus polyrhizus (4744 seeds) in flowers pollinated with pollen from Hylocereus undatus.

Thus, the smaller quantity of seeds per fruit in January is possibly related to the viability of the pollen and the quantity of fertilized ovules, which consequently affected the size of the fruit obtained. Probably, the quantity of pollen deposited on the stigmas of the flowers also had an effect on fertilization of the ovules, affecting seed production.

In relation to the chemical characteristics, it may be observed from Table 4 that both in Jan. and in Apr., the fruit obtained by manual self-pollination differs from the fruit of manual cross pollination in the characteristics of titratable acidity and ratio (SS/AT). The time period of pollination, for its part, affects all the chemical characteristics evaluated
(SS, pH, AT, SS/AT) in both types of fruit, with greater soluble solids and titratable acidity values being found in flowers pollinated in Apr.

In general, the fruit pollinated in Jan. had greater $\mathrm{pH}$ values (4.58 and 4.47) and consequently less titratable acidity (0.16 and 0.22$)$ for selfpollinating flowers and cross pollination respectively, since they are inverse characteristics. The soluble solids contents are greater when the flowers are pollinated in Apr., which provides a greater value in the ratio of the fruit, since this represents the ratio between SS/AT. The $\mathrm{pH}$ values, titratable acidity and ratio in this study are greater than those found by Silva et al. (2011), and the soluble solids contents are similar.

Germination of the seeds was not affected by the type of fruit, or by the time period of pollination (Table 4), exhibiting high germinative power, up to a $98 \%$ germination rate. Thus, the two types of pollination, regardless of the time period, generate viable seeds. Lower values in germination of pitaya were found by Alves et al. (2011) using different substrates, obtaining $85 \%$ as the maximum of germinated seeds at $25^{\circ} \mathrm{C}$ in a roll of paper.

Table 4. Chemical characteristics related for soluble solids contents, $\mathrm{pH}$, titratable acidity, ratio and germination percentage of pitaya fruit seeds resulting from two types of pollination and two time periods of pollination. Lavras, 2012.

\begin{tabular}{|c|c|c|c|}
\hline & \multirow{2}{*}{$\begin{array}{l}\text { Type of manual } \\
\text { pollination }\end{array}$} & \multicolumn{2}{|c|}{ Time period of pollination } \\
\hline & & Jan. & Apr. \\
\hline \multirow{2}{*}{$\begin{array}{l}\text { Soluble solids } \\
\text { contents (SS) }\end{array}$} & Self-pollination & $11.72 \mathrm{a} B$ & 13.74 a A \\
\hline & Cross pollination & $12.08 \mathrm{a} \mathrm{B}$ & $14.28 \mathrm{a} \mathrm{A}$ \\
\hline \multirow[t]{2}{*}{$\mathrm{pH}$} & Self-pollination & 4.58 a $\mathrm{A}$ & 4.12 a B \\
\hline & Cross pollination & 4.47 a $\mathrm{A}$ & 3.97 a B \\
\hline \multirow{2}{*}{$\begin{array}{l}\text { Titratable Acidity } \\
\text { (AT) }\end{array}$} & Self-pollination & $0.16 \mathrm{~b} \mathrm{~B}$ & $0.34 \mathrm{~b} \mathrm{~A}$ \\
\hline & Cross pollination & 0.22 a B & 0.54 a $\mathrm{A}$ \\
\hline \multirow[t]{2}{*}{ Ratio (SS/AT) } & Self-pollination & 78.17 a A & $45.01 \mathrm{a} \mathrm{B}$ \\
\hline & Cross pollination & $54.76 \mathrm{~b} \mathrm{~A}$ & $23.96 \mathrm{~b} \mathrm{~B}$ \\
\hline \multirow[t]{2}{*}{ Germination (\%) } & Self-pollination & 93.0 a $\mathrm{A}$ & 98.0 a $\mathrm{A}$ \\
\hline & Cross pollination & $98.0 \mathrm{a} \mathrm{A}$ & $95.50 \mathrm{a} \mathrm{A}$ \\
\hline
\end{tabular}

Mean values followed by the same small letter in the column and the same capital letter in the line do not differ among themselves by the Tukey test at $1 \%$ probability.

Silva et al. (2011), pollinating pitaya at different time periods of the year (Mar. and Apr.) report that the climatic conditions during development of the fruit affect its quality. Nomura et al. (2005) studying changes in the sugar and acid content in pitaya during development of the fruit observed that the fruit collected in the summer had lower soluble solids content than those collected in the fall. Thus, the differences found in the characteristics of the fruit in this study may be related to environmental factors, since the pollinations were performed at different seasons of the year (summer and fall).

\section{CONCLUSIONS}

Artificial pollination in pitaia is an alternative for areas where natural pollinators are scarce. 
The time period of pollination affects the physical and chemical characteristics of the fruit, as well as the type of manual pollination used (selfpollination and cross pollination), but does not affect the germination of pitaya seeds.

\section{ACKNOWLEDGMENTS}

The authors would you like to say thank you to CNPq, CAPES and FAPEMIG for the financial support and for the scholarship.

RESUMO: Nativa das Américas, a pitaia é atualmente uma frutífera em expansão no mercado nacional e internacional, sendo uma alternativa de renda aos pequenos e grandes produtores. Como alguns estudos demonstram a ineficiência de polinizadores naturais na frutificação da pitaia, realizou-se este trabalho objetivando-se estudar a eficiência da autopolinização manual e da polinização manual cruzada em Hylocereus undatus, em duas épocas. O experimento foi instalado no pomar da Universidade Federal de Lavras, em delineamento inteiramente casualizado, em esquema fatorial 2 x 2 (dois tipo de polinização e duas épocas de florescimento), com 15 repetições, sendo um flor por repetição. As flores foram ensacadas, emasculadas e polinizadas manualmente. Foram avaliadas a percentagem de pegamento dos frutos, diâmetro longitudinal e transversal dos frutos, massa de fruto, polpa e casca, espessura de casca, teores de sólidos solúveis, $\mathrm{pH}$, acidez titulável, ratio (sólidos solúveis:acidez titulável), número de sementes por fruto e germinação das sementes. Concluiu-se que a polinização em pitaia vermelha com o próprio pólen permite a frutificação. Flores polinizadas em abril resultam em frutos com características físicas superiores aos frutos gerados em janeiro.

PALAVRAS-CHAVE: Polinização cruzada. Hylocereus undatus (Haw.) Britton \& Rose. Melhoramento vegetal. Autopolinização.

\section{REFERENCES}

Andrade, R. A. de.; Oliveira, I. V. M.; Martins, A. B. G. 2005. Influência da condição e período de armazenamento na germinação de sementes de pitaya-vermelha. Revista Brasileira de Fruticultura, v. 27, p.168-170. http://dx.doi.org/10.1590/S0100-29452005000100044

Alves, C. Z.; Godoy, A. R.; Correa, L. de. S. 2011. Adequação da metodologia para o teste de germinação de sementes de pitaia vermelha. Ciência Rural, v. 41, p. 779-784. http://dx.doi.org/10.1590/S010384782011005000051

Canto, A. R. 1993. El cultivo de pitahaya en Yucatan. Gobierno Del Estado de Yucatan: Universidad Autônoma Chapingo, 53p.

Cisneros, A.; Garcia, R. B.; Tel-Zur, N. 2011. Ovule morphology, embryogenesis and seed development in three Hylocereus species (Cactaceae). Flora, v. 206, p. 1076- 1084.

http://dx.doi.org/10.1016/j.flora.2011.07.013

Gunasena, H. P. M.; Pushpakumara, D. K. N. G.; Kariyawasam, M. 2007. Dragon fruit (Hylocerus undatus (Haw.) Britton and Rose). In: Pushpakumara, D. K. N. G.; Gunasena, H. P. M.; Singh, V. P. Underutilized fruit trees in Sri Lanka. World Agroforestry Centre, South Asia Office; New Delhi, India, 2007. cap.4, p. 110-142.

Le Bellec F (2004) Pollinisation et fecundation de Hylocereus undatus et de H. costaricensis à I'île de la Réunion. Fruits, v. 59, p. 411-422. http://dx.doi.org/10.1051/fruits:2005003

Le Bellec, F.; Vaillant, F.; Inbert, E. 2006. Pitahaya (Hylocereus spp.): a new crop, a market with a future. Fruits, v. 61, p. 237-250. http://dx.doi.org/10.1051/fruits:2006021

Marques, V. B.; Amato, R. A.; Ramos, J. D.; Araujo, N. A. de.; Silva, F. O. dos. R. 2011. Fenologia reprodutiva de pitaia vermelha no município de Lavras, MG. Ciência Rural, v. 41, p. 984-987. http://dx.doi.org/10.1590/S0103-84782011005000071 
Merten, S. 2003 A review of Hylocereus production in the United States. J. Prof. Assoc. Cactus Developmt, v. 5, p. $98-105$.

Mizrahi, Y.; Nerd, A.; Nobel, P. S. 1997. Cacti as crop. Horticultural Review, v. 18, p. 291-320.

Mizrahi, Y.; Mouyal, J.; Nerd, A.; Sitrit, Y. 2004. Metaxia in the Vine Cacti Hylocereus polyhizus and Selenicereus ssp. Annals of Botany, v. 93, p. 469-472. http://dx.doi.org/10.1093/aob/mch055

Moreira, R. A.; Ramos, J. D.; Marques, V. B.; Araujo, N. A. de.; Melo, P. C. de. 2011. Crescimento de pitaia vermelha com adubação orgânica e granulado bioclástico. Ciência Rural, v. 41, p. 785-788.

http://dx.doi.org/10.1590/S0103-84782011010500002

Nomura, K.; Ide, M.; Yonemoto, Y. 2005 Changes in sugars and acids in pitaya (Hylocereus undatus) fruit development. Journal of Horticultural Science \& Biotechnology, 80:711-715.

Imbert, E. 2001 La pitahaya, un marché en devenir. Fruitrop, v. 80, p. 13.

Silva, A. C. C. ; Martins, A. B. G.; Cavallari, L. L. 2011. Qualidade de frutos de pitaya em função da época de polinização, da fonte de pólen e da coloração da cobertura. Revista Brasileira de Fruticultura, v. 33, p. 11621168. http://dx.doi.org/10.1590/S0100-29452011000400014

Weiss, J.; Nerd, A.; Mizrahi, Y. 1994. Flowering behavior and pollination requirements in climbing cacti with fruit crop potential. HortScience, v. 29, p. 1487-1492. 